\title{
Donna Braquet
}

\section{Past overdue!}

\section{Protections for LGBT Americans in the workplace}

M arriage equality has made great strides in the courts and in public opinion polls in recent years, but even though these momentous changes are happening, lesbian, gay, bisexual, and transgender (LGBT) Americans continue to be fired and harassed for who they are and who they love. Currently, there are still 29 states in which employees can be fired for their sexual orientation and 32 states in which they can be fired for their gender identity, meaning that an estimated 4.3 million LGBT Americans live in states without protections for sexual orientation or gender identity. ${ }^{1}$

The reality of this lack of protections can be seen in results of a 2013 study which found that $53 \%$ of LGBT workers are closeted at work and 35\% felt the need to lie about their personal lives in the workplace. One-fifth reported wanting to leave their jobs and stated that they felt mental and emotional fatigue from hiding their orientation or identity. ${ }^{2}$

Although President Obama signed an executive order in April 2015 that protects federal employees and prohibits discrimination by any federal contractors, ${ }^{3}$ there are no federal laws protecting LGBT workers from discrimination. The Employment Non-Discrimination Act (ENDA) languished in Congress for decades and has all but been abandoned by most LGBT advocacy organizations due to concerns over the inclusion of overly broad religious exemptions. Most LGBT groups and a growing number of legislators now advocate for a comprehensive civil rights bill like that of the Civil Rights Act of 1964, as opposed to a stand alone ENDA bill. ${ }^{4}$ Such a civil rights bill would be comprehensive, protecting employment and also credit, education, federal funding, housing, jury service, and public accommodations. The resources below shed light on the long, difficult, and winding, and frankly well past overdue, path to LGBT workplace protections in America.

\section{Timelines}

Note: Many of the timelines below have not been updated in recent months due to the abandonment of ENDA. However, they serve as historical snapshots.

- CNN. This timeline, last updated in 2013, begins in 1974, when protections for sexual orientation was first introduced in the House of Representatives. Access: http://www. cnn.com/2013/11/04/politics/employment -nondiscrimination-timeline/index.html.

- The Leadership Conference. A group of more than 200 national organizations that promote civil rights, The Leadership Conference has a timeline of ENDA news reports. Access: http://www.civilrights.org/lgbt/enda/.

- Washington Blade. One of the most popular LGBT news sites hosts a timeline of employment nondiscrimination-proposed legislation from 1974 to 2014. Access: http:// www. washingtonblade.com/2014/05/14 /endas-long-frustrating-path/.

Donna Braquet is biology librarian and director of the LGBT Center at University of Tennessee-Knoxville, email: dbraquet@utk.edu

(c) 2015 Donna Braquet 


\section{Infographics and maps \\ - Center for American Progress.}

This infographic shows results from a 2013 ENDA National Poll Results such as states approving of protections, religious breakdown, and political party affiliation. Access: https://www.americanprogress.org/issues /lgbt/news/2013/10/31/78473/infographic -americans-agree-on-enda/.

- The Guardian. The United Kingdom newspaper released an infographic of LGBT rights in America viewed by states and regions. Employment is included among marriage, adoption, housing, schools, and hate crimes. Access: http://www.theguardian.com /world/interactive/2012/may/08/gay-rights -united-states.

- Movement Advancement Project (MAP). MAP represents complex LGBT issues in easy to understand graphical and tabular format. This site provides an interactive map of the United States, which shows availability of protections for sexual orientation and gender identity on state and local levels. Access: http://www.lgbtmap.org/equality-maps /employment_non_discrimination_laws.

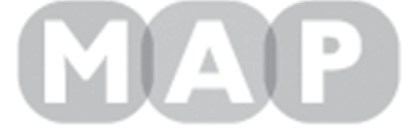

\section{movement advancement project}

- National Center for Transgender

Equality. This map shows which states have clear protections against discrimination based on gender identity, which ones are protected by sex and sexual orientation, and which are protected based on sex alone. Access: http:// transequality.org/issues/resources/map-state -transgender-non-discrimination-laws.

- Transgender Law Center. These sets of maps allow for snapshots of nondiscrimination issues, such as workplace, housing, public access, and credit among state laws and local ordinances. Access: http:// transgenderlawcenter.org/equalitymap.

\section{Advocacy organizations}

- Lambda Legal. Founded in 1973, Lambda Legal is the oldest and largest legal policy advocacy organization in the United States. The workplace page provides updates on current cases and provides workplace rights information and best practices for companies related to LGBT employment. Access: http:// www.lambdalegal.org/issues/employment -and-rights-in-the-workplace.

\section{- National Center for Lesbian Rights} (NCLR). Founded in 1977, NCLR works through litigation, legislation, policy, and education to advance the civil rights of LGBT people. NCLR's employment page provides updates regarding litigation, policy changes, and legislative votes. Access: http://www. nclrights.org/explore-the-issues/employment/.

- National Center for Transgender Equality. The leading social advocacy group for transgender people was founded in 2003. The employment page provides legal information, as well as practical information on how to resolve workplace discrimination. Access: http://transequality.org/know-your -rights/employment-general.

\section{Resources for LGBT workers}

- Corporate Equality Index. This yearly report rates more than 700 U.S. companies based on their LGBT employee inclusion and support by measuring benefits, policies, diversity training, and public commitment. Access: http://www.hrc.org/campaigns/ corporate-equality-index.

- Human Rights Campaign (HRC) Employer Database. This database of more than 1,000 companies can be searched by company name, but is also browsable by several variables such as 1) inclusivity of gender identity in the nondiscrimination clause, 2) by type of organization (for-profit; college and university; not for-profit; unions), 3) employers that offer domestic partner benefits, and 4) LGBT employee network. Access: http://www.hrc.org/resources /entry/search-our-employer-database.
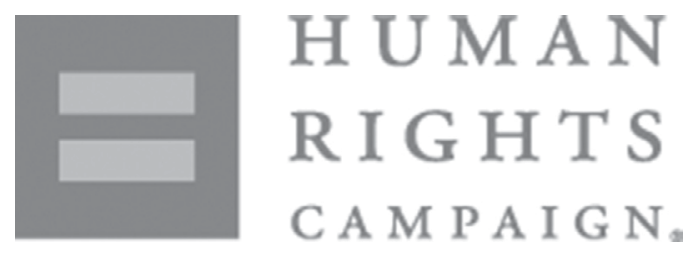
- HRC Workplace. Possibly the most well known LGBT rights organization, HRC provides a robust workplace site that includes resources for employees, co-worker, employers, as well as a plethora of additional resources. Access: http://www.hrc. org/topics/workplace.

- Out \& Equal Workplace Advocates. The world's largest nonprofit organization specifically dedicated to helping companies support their LGBT employees, including online training, on-site training, toolkits, and a virtual summit series. Access: http://www. outandequal.org/.

\section{Resources for employers and co- workers}

- Catalyst. This nonprofit organization focuses on providing opportunities for women in businesses. The running list of reports, trainings, webinars, and other resources geared toward diversity in the workforce, including LGBT. Access: http://www.catalyst. org/knowledge/topics/lgbtqi.

- Human Rights Campaign. Possibly the most comprehensive list of resources for employers, HRC provides tools that provide guidance on speaking to inclusion, restroom usage, transitioning employees, international business considerations, recruitment, inclusive policies, philanthropy for LGBT issues, and best practices. Access: http://www.hrc.org/resources/entry /employer-resources.

- Lambda Legal. This advocacy and litigation organization provides a quick to read list of most frequently asked questions by employers in a simple question and answer format. Access: http://www.lambdalegal.org /know-your-rights/workplace/for-employers.
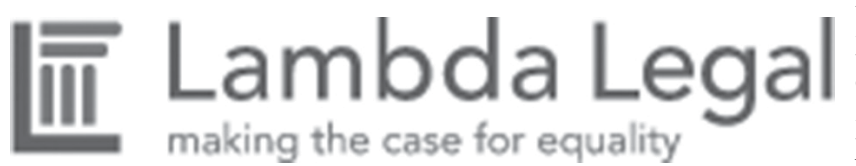

Access: http://www.straightforequality.org /WorkplaceMaterials.

\section{Current awareness}

- American Civil Liberties Union. This blog posts news stories, videos, and documents, such as amicus briefs related to LGBT discrimination cases. Access: https://www. aclu.org/issues/lgbt-rights.

- DiversityInc. DiversityInc's newsblog provides up-to-date stories related to policies, legislation, and media. Access: http://www. diversityinc.com/tag/lgbt-rights/.

- The Huffington Post. This newsroll provides stories concerning LGBT job discrimination from Huffington Post's main site. Access: http://www.huffingtonpost.com /news/lgbt-workplace-discrimination/.

- The National Center for Transgender Awareness. This blog provides current news and analysis related to issues of gender identity and gender expression. Access: http:// transequality.org/issues/non-discrimination -laws.

- Lambda Legal. This newsblog provides links to legal analysis regarding job discrimination of LGBT employees. Access: http://www.lambdalegal.org/blog/topic/ employment-and-rights-in-the-workplace.

\section{Governmental guidance}

- Department of Labor. This page covers the protections of transgender employees covered under sex-based discrimination and harassment. It provides key terminology, employee rights, and employer/management's responsibilities. Access: http://www.dol.gov/oasam/programs/ crc/20130712GenderIdentity.htm.

\section{- President Obama and the LGBT Commu-} nity. This page highlights LGBT policy issues advanced by President Obama, including workplace protections. Access: https://www. whitehouse.gov/lgbt.

- Straight for Equality in the Workplace. This site provides resources on how to be a straight ally to co-workers including a training manual, top ten lists, and a glossary.
- U.S. Equal Employment Opportunity Commission (EEOC). This page provides updates on EEOC litigation related to Title VII \& LGBT Related Discrimination and provides 
an overview of EEOC's role in protection from discrimination. Access: http://www.eeoc.gov /eeoc/newsroom/wysk/enforcement _protections_lgbt_workers.cfm, http://www. eeoc.gov/federal/directives/lgbt_complaint _processing.cfm.

\section{U.S. Equal Employment} Opportunity Commission

\section{Major reports}

- A Broken Bargain. This 2013 collaborative report from Human Rights Campaign, Center for American Progress, and Movement Advancement Project presents ten barriers that place LGBT employees at a disadvantage in the workplace. Statistics on the number of LGBT workers and suggestions for removing barriers are included. Access: http://www.lgbtmap.org/ file/a-broken-bargain-full-report.pdf.

\section{- A Broken Bargain for LGBT Work-} ers of Color. Released as a supplement to "A Broken Bargain," this report focuses on the barriers in place specific to people of color, including education, hiring bias, and unequal pay. Access: http://nbjc.org/sites/default /files/a-broken-bargain-for-lgbt-workers-of -color.pdf.

\section{- A Broken Bargain for Transgender} Workers. Released as a supplement to "Broken Bargain: Discrimination, More Taxes, and Fewer Benefits," this report focuses on the additional barriers faced by transgender people in the workplace. The study finds limited protections, inequitable health policies, and hiring biases. The report provides a good mix of infographics, tables, maps, and personal stories in addition to data tables and findings. Access: http://www.lgbtmap.org /transgender-workers.

- Business Impact of LGBT-Supportive Workplace Policies. The Williams Institute, a policy research arm of the UCLA School of Law, released this report in May 2013. The study found that supportive policies are tied to positive business outcomes, and increased job commitment and satisfaction. Access: http://williamsinstitute.law.ucla.edu /research/workplace/business-impact-of-lgbt -policies-may-2013/.

- Cost of the Closet and the Rewards of Inclusion. This 2014 follow up to HRC's 2009 "Degrees of Equality" report shows that despite improving societal conditions for LGBT Americans, they still face great discrimination in the workplace. For example, the survey found that $53 \%$ of LGBT workers hide who they are in the workplace. Access: http://www.hrc.org/resources/entry/the-cost -of-the-closet-and-the-rewards-of-inclusion.

- The Costly Business of Discrimination. This 2012 report by the Center for American Progress quantifies the fiscal cost to discrimination and unfairness due to recruitment, retention, job performance, marketing, and litigation. Access: https://www.americanprogress.org/issues/lgbt /report/2012/03/22/11234/the-costly -business-of-discrimination/.

- Injustice at Every Turn. A survey of more than 6,000 transgender Americans in 2011 found that transgender workers face inequality in wages, harassment, and discrimination, and thus greater economic instability. Access: http://endtransdiscrimination.org/report.html.

- Left Behind. This 2014 report discusses the barriers faced particularly by LGBT youth who are more likely to be out at a younger age than previous generations. Barriers include education, homelessness, and poverty, and the report provides suggestions for improvement. Access: https://cdn.americanprogress. org/wp-content/uploads/2014/07/LGBTyouthJobsreport.pdf.

- State Employment Discrimination Reports. Created by the Williams Institute of UCLA School of Law, these reports quantify the impact that discrimination has on each state. Access: http://williamsinstitute.law.ucla.edu/category/ research/workplace/.

- Working in the Shadows. The ACLU released this report in 2007, which is a combination of studies that support employment protections as well as personal narratives of those who have been affected by workplace discrimination and firing. Access: https://www.aclu.org/files/pdfs/lgbt /enda_20070917.pdf.

(continues on page 322) 
exists a "statistically significant" link between attention deficit and lower academic performance with time spent on social networking sites in "Effect of online social networking on student academic performance," Computers in Human Behavior 28 (2012): 2117-2127. See also M. Prensky, Brain Gain: Technology and the Quest for Digital Wisdom (Palgrave Macmillan: New York, 2012).

3. K. L. Wolever et al., "Effective and viable mind-body stress reduction in the workplace: A randomized controlled trial," Journal of Occupational Health Psychology, 17.2 (2012): 246-58.

4. B. Michels, D. Maxwell, and C-W. Chang, "Labyrinths: Yesterday, Today and TomorrowImplications for Education," Critical Questions in Education, 1:1 (2011): 26-39.
5. M. Shindle, "Walking the Labyrinth: An exercise in self-healing," American Nurse Today 3.8 (2008): 28-29.

6. J. Rhodes, "Commonly Reported Effects of Labyrinth Walking," Labyrinth Pathways (2008).

7. M. Zucker, "Labyrinth Walking in Corrections," Journal of Addictions Nursing 23 (2012): 47-54. Available at: http://works. bepress.com/donna_zucker/19.

8. P. Grossman, L. Neimann, S. Schmidt, and $\mathrm{H}$. Walach, "Mindfulness-based stress reduction and health benefits: A meta analysis," Journal of Psychosomatic Research 57 (2004): 35-43; see also K. Baicker, D. Cutler, and Z. Song, "Workplace wellness programs can generate savings," Health Affairs 29.2 (2010): 304-11. $\boldsymbol{n}$
"Micro assessing" (cont. from page 304)

and even remote researchers-patron groups that often fall outside of traditional feedback and assessment data collection mechanisms, patron groups that we may never see or know about beyond as a blip in our web analytics. The concreteness of the individual stories in the logs helps the library stay attuned to the variety of patron activity and to plan services and resources creatively.
Library Impact Story Logs. Simple idea. Big return.

\section{Note}

1. "Theological Commons," Princeton Theological Seminary Library, accessed September 10, 2014, http://commons.ptsem. edu. $\boldsymbol{n}$

"Past overdue!" (cont. from page 316)

\section{Opposition}

- Family Research Council (FRC). FightENDA.org is a campaign of FRC Action. This arm of the FRC, formed in 1992, was formed to educate society on the "traditional American values." Though the website has not been updated since 1993, it outlines the reasoning behind their opposition to employment protections for LGBT Americans. Access: http://www.fightenda.org/.

- The Heritage Foundation. This think tank, created in 1973 promotes conservative public policies. This page outlines the danger of providing workplace protections under ENDA and proposes that increased employment protections would weaken the First Amendment, lead to same-sex marriage, and threaten businesses. Access: http://www. heritage.org/research/reports/2013/11/endathreatens-fundamental-civil-liberties.

\section{Notes}

1. http://www.americanprogress.org/issues/lgbt/report/2013/06/04/65133/a-broken -bargain/.

2. http://www.advocate.com/employment -discrimination/2014/05/08/study -majority-lgbt-workers-closeted-job.

3. https://www.whitehouse.gov /blog/2015/04/08/another-step-toward -equality-lgbt-workers.

4. http://www.nytimes.com/2014/12/05 /us/advocates-seek-civil-rights-bill-for -lesbian-gay-bisexual-and-transgender -americans.html. $\mathbf{n}$ 